\title{
INTERNAL ANATOMY AND SKELETAL TAPHONOMY OF MARINE SEQUENCES: VARIATION WITH SUBSIDENCE
}

\author{
KIDWELL, Susan M., Dept. of Geophysical Sciences, University of Chicago, 5734 S. \\ Ellis Ave., Chicago, IL 60637 U.S.A.
}

Skeletal concentrations are common foci for paleontologic collecting, yet vary widely in their expected levels of taphonomic bias, particularly temporal resolution and biological fidelity. Basic concentration types include: (1) simple event-concentrations composed of anything from autochthonous-census, entirely exotic, or entirely remanié assemblages (e.g., shelly tempestites, shell-lined burrows); (2) composite concentrations of many stacked to complexly amalgamated events, accumulated in normal to expanded thickness (e.g., bioherms, shell banks \& fans); (3) stratigraphically condensed hiatal concentrations having an even greater minimum degree of assemblage-level taphonomic bias (e.g., transgressive shelly sands, sediment-starved bone beds); and (4) lag-concentrations formed by erosion/corrosion of significant section and composed typically of highly culled and time-disordered skeletal material. Detailed field study of three temperate to subtropical basins in North America and reconnaissance of other basins at similar and lower paleolatitudes indicate that these four concentration types are distributed systematically within unconformity-bounded sequences and, moreover, that marine sequences vary qualitatively both in their stratigraphic anatomy (e.g. Van Wagoner et al., 1990; Einsele \& Bayer, 1991) and skeletal taphonomy as a function of long-term subsidence.

I. Basins of moderate subsidence (total 10's $\mathrm{cm} / \mathrm{ka}$ maintained over 1-10 ma) are characterized by "textbook" sequences composed of discrete upward-shallowing parasequences in transgressive and highstand/regressive marine phases. Taphonomically, sequences in these settings typically contain a variety of concentration types, and therefore require careful taphonomic differentiation. In the shale-rich Cretaceous Ostracode Zone (Alberta foreland basin; Banerjee \& Kidwell, 1991), for example, composite shell beds mark the tops of parasequences near the basin margin, event-beds of granulated shell mark the bases of parasequences further offshore, and diagenetically complex, shell-poor hiatal limestones mark maximum flooding surfaces in the most distal areas.

II. Basins of high subsidence (total 100's $\mathrm{cm} / \mathrm{ka}$ maintained over $\geq 1 \mathrm{ma}$ ) are typically characterized by expanded sequences with vague parasequences; sedimentary cyclicity is linked more clearly to local tectonism and autocyclic environments than to eustasy. Taphonomically, these records are dominated by comparatively straightforward event- and composite concentrations. In the Mio-Pliocene Salton Trough (Gulf of California rift basin), for example, oyster bioherms and shell-ridges cap upward-shallowing delta-front cycles, and coral-bearing bioclastites occur along the distal toes of coastal alluvial fans and are banked against inter-fan rocky shorelines. Hiatal concentrations are poorly developed, even along downlap surfaces, and laterally extensive lags are rare.

III. Basins of low subsidence (total $\leq$ few $\mathrm{cm} / \mathrm{ka}$ maintained over 1-10 ma) are characterized by stratigraphically telescoped sequences with poorly developed (and locally deepening-up) "parasequences"; transgressive surfaces largely coincide with sequence boundaries. Hiatal and lag concentrations are relatively common and close-spaced stratigraphically; these may be taxonomically diverse even in temperate latitudes owing to environmental condensation, and in all instances are taphonomically complex. In the Miocene Chesapeake Group (outcropping U.S. Altantic passive margin), 4 transgressive hiatal shell concentrations lie within $40 \mathrm{~m}$ of section; each contains up to $\sim 100$ species and rests directly on a 3rd-order sequence boundary. A starved hiatal bone bed with high microplankton diversity marks the major 2nd-order downlap surface; lags of comminuted bones, teeth, and mollusk steinkerns mantle shallow-water unconformities near lap-out. 